\title{
Type-III hereditary angioedema resolved by surgery
}

\author{
Lisa W Fu*, Fanny Silviu-Dan \\ From Canadian Society of Allergy and Clinical Immunology Annual Scientific Meeting 2014 \\ Ottawa, ON, Canada. 23-26 October 2014
}

\section{Background}

In classic hereditary angioedema, inadequate $\mathrm{C} 1$-inhibitor (C1-INH) failing to restrict factor-XII activity leads to increased production of bradykinin, a potent vasodilator and mediator of angioedema. Hereditary angioedema with normal C1-INH (Type-III) manifests with sporadic recurrent angioedema but normal C1-INH concentration and activity. Here, bradykinin accumulation appears dependent on Factor XII and Factor XII gene mutations are sometimes found. Type-III angioedema affects almost exclusively females, worse in pregnancy, on oral contraceptives as estrogen may increase total bradykinin. Diagnosis is difficult given the clinical heterogeneity and lack of biochemical indicators. Treatment carries various risks when given for prophylaxis and a challenge for timely administration in an acute crisis. This is the first case report in the literature of a woman whose repeated angioedema episodes resolved with surgical resection of an ovarian cyst.

\section{Case presentation}

A 41-year-old woman presented with recurrent severe episodes of face, tongue, and throat swelling occurring under variable circumstances and without clear triggers. $\mathrm{C} 4$ and $\mathrm{C} 1-\mathrm{INH}$ level and function were normal. Many years after symptom onset, a large ovarian cyst was diagnosed. Measured estrogen level was high. Once the cyst was surgically removed, no further angioedema occurred. Recently a son developed vibratory angioedema, a rare form of physical urticaria. A first cousin and niece in Italy have angioedema. Genome exome sequencing is underway to determine if specific genetic variations are contributing to this family cluster of angioedema.

Department of Medicine, McGill University, Montreal, QC, Canada

\section{Conclusion}

Resolution of Type-III hereditary angioedema manifestations by surgery upon diagnosing ovarian cysts as the source of estrogen excess adds a new facet to the evaluation and therapy for this condition. This family cluster of angioedema proposes an interesting question of genetic variations predisposing to angioedema.

\section{Consent}

Written informed consent was obtained from the patient for publication of this abstract and any accompanying images. A copy of the written consent is available for review by the Editor of this journal.

Published: 18 December 2014

doi:10.1186/1710-1492-10-S2-A10

Cite this article as: Fu and Silviu-Dan: Type-III hereditary angioedema resolved by surgery. Allergy, Asthma and Clinical Immunology 2014 10(Suppl 2):A10.

Submit your next manuscript to BioMed Central and take full advantage of:

- Convenient online submission

- Thorough peer review

- No space constraints or color figure charges

- Immediate publication on acceptance

- Inclusion in PubMed, CAS, Scopus and Google Scholar

- Research which is freely available for redistribution 